\title{
Relationship Between Ischemic Stroke Subtypes and Migraine with Visual Aura
}

\author{
İskemik İnme Alt Tipleri ve Görsel Auralı Migren İlişkisi
}

\section{Relationship Between Ischemic Stroke Subtypes and Migraine with Visual Aurai}

Epidemiologic studies have shown that migraine with aura is associated with increased risk of ischemic stroke. A recent review on migraine and stroke provided neuroimaging and genetic evidence supporting the relationship between migraine with aura and ischemic stroke. Furthermore, subclinical infarcts have been associated with migraine. However, there is not enough information to illuminate the pathologic mechanism underlying increased risk of ischemic stroke in migraine with aura. For this reason, we aimed to examine the relationship between ischemic stroke and migraine with and without aura, and especially assess the association between ischemic stroke subtypes (thrombotic, cardioembolic, lacunar) and migraine with and without aura in the study 'Atherosclerosis Risk in Communities' (ARIC). Participants who completed the $3^{\text {rd }}$ clinical visit of ARIC $(n=12.882)$ between 1993 and 1995 were included in this longitudinal, community-based cohort study. Patients with first ischemic stroke before this date $(n=87)$ and with no headache information $(n=37)$ were excluded. Analyses were performed with a total of 12.758 participants and those without headache anamnesis were included in the control group. Participants were assessed using Modified International Classification of Headache Disorders; 3 beta questionnaires, which were administered at the $3^{\text {rd }}$ ARIC visit. The demographic characteristics of the participants and the risk factors for stroke are shown in Table 1 . Ischemic strokes due to vascular events were recorded during the followup period up to December 2012 and subtypes were identified.

At the end of the analysis, migraine headache was found in $13 \%$ of participants and visual aura in $4 \%$. During followup, the rate of ischemic stroke in the whole population was $6 \%$, whereas ischemic stroke was seen in $5 \%$ of patients with migraine (with/without visual aura) during the same period. When compared with participants without headache, a significant relationship was found between migraine with visual aura and ischemic stroke $(p=0.008)$. Significantly increased risk of cardioembolic stroke was found in migraineurs with visual aura compared with those without visual aura $(\mathrm{p}=0.003)$.

This study suggests that there may be a common pathogenesis between cardiac embolism and migraine with visual aura, or that visual aura symptoms may be associated with distal embolism; it also emphasizes the need for further studies to evaluate predisposing factors that can cause cardioembolism in patients with migraine who have visual aura. The 'Women's Health Study' yielded that cryptogenic stroke was the most common stroke in patients with migraine with aura. On the other hand, patent foramen ovale (PFO), a common condition in autopsy series and seen in $25 \%$ of the population, is detected using transesophageal echocardiography in $40-50 \%$ of cryptogenic strokes. However, there are no data on cryptogenic stroke and PFO in the ARIC study. On the other hand, there are limitations to the algorithms that determined stroke subtypes in the study. Among the other limitations of the

Address for Correspondence/Yazışma Adresi: İpek Güngör Doğan MD, Darıca Farabi State Hospital, Clinic of Neurology, Kocaeli, Turkey

Phone: +905355106577 E-mail: dripekgngr@gmail.com

Received/Geliş Tarihi: 03.01.2017 Accepted/Kabul Tarihi: 19.02.2017

${ }^{\circ}$ Copyright 2017 by Turkish Neurological Society

Turkish Journal of Neurology published by Galenos Publishing House. 


\begin{tabular}{|c|c|c|c|c|}
\hline & $\begin{array}{c}\text { Migraine with } \\
\text { visual aura }(\mathrm{n}=463) \\
\mathrm{n}(\%)\end{array}$ & $\begin{array}{c}\text { Migraine without visual } \\
\text { aura }(\mathrm{n}=1159) \\
\mathrm{n}(\%)\end{array}$ & $\begin{array}{l}\text { Non-migraine } \\
\text { headaches } \\
(\mathrm{n}=1.083) \\
\mathrm{n}(\%)\end{array}$ & $\begin{array}{l}\text { No headache } \\
(\mathrm{n}=10.053) \\
\mathrm{n}(\%)\end{array}$ \\
\hline Mean age (years) & 59 & 58 & 59 & 60 \\
\hline Female & $376(82)$ & $874(75)$ & $672(62)$ & $5.184(51)$ \\
\hline White race & $371(81)$ & $997(86)$ & $911(84.7)$ & $7.504(74.7)$ \\
\hline African American & $85(18.5)$ & $160(13.8)$ & $165(15)$ & $2.513(25)$ \\
\hline Others & $2(0.5)$ & $1(0.2)$ & $4(0.31)$ & $31(0.3)$ \\
\hline Obesity (BMI >30) & $169(37)$ & $329(28)$ & 305 (28) & $3.413(34)$ \\
\hline Hypertension & $221(48)$ & $426(37)$ & $394(36)$ & $4.053(40)$ \\
\hline Diabetes & $47(10)$ & $87(7.5)$ & $83(7.7)$ & $1.014(10)$ \\
\hline Smoking & $242(53)$ & $616(53)$ & $634(59)$ & $6.004(60)$ \\
\hline Hyperlipidemia (LDL >100 mg/dL) & $356(77)$ & $890(77)$ & $805(74)$ & $7.846(78)$ \\
\hline NSAID use & $136(30)$ & $295(25)$ & $215(20)$ & $1.569(16)$ \\
\hline Physical activity* & $257(55)$ & $714(62)$ & $648(60)$ & $6.233(62)$ \\
\hline
\end{tabular}

study was that the headache questionnaires were designed in 1995, retrospective questioning was conducted at an older age, and the diagnosis of headache was made without a headache specialist (1).

\section{Reference}

1. Androulakis XM, Kodumuri N, Giamberardino LD, Rosamond WD, Gottesman RF, Yim E, Sen S. Ischemic stroke subtypes and migraine with visual aura in the ARIC study. Neurology 2016;87:2527-2532. 